\title{
SOME ECOLOGICAL EFFECTS OF UNDERWATER SELF-EXPLOSION OF AMMUNITION IN LAKE LOMTJÄRN, SWEDEN: THE IMPACT FROM MERCURY
}

\author{
B. E. LILJEDAHL, U. QVARFORT, R. BERGLIND, P. LEFFLER \& J. SJÖSTRÖM \\ Swedish Defence Research Agency, SE-901 82 Umeå, Sweden.
}

\begin{abstract}
After the Second World War, dumping in lakes was a rational way to solve the security problem with the extensive amount of unreliable or unused ageing ammunition. Most commonly the ammunition was dumped in sealed boxes or as pieces. In some cases the ammunition was deliberately detonated when dumped. In Lake Lomtjärn, a small lake in central Sweden, extremely high levels of mercury $(300 \mathrm{mg} / \mathrm{kg}$ dry weight $\mathrm{Hg}$ ) were detected in the sediments. The mercury was expected to originate from years of dumping followed by an underwater self-explosion of ignition capsule containing mercury. The lake is unique in the sense that the mercury levels are among the highest found so far in Sweden and that no other source of pollutant is present in the area. The aim of this study was to evaluate the environmental impact from the underwater explosion. Samples of sediment, bottom water, surface water, bottom fauna, littoral fauna and fish (muscle and liver) were analysed for metals as well as physical parameters in order to investigate effects on biota. Acute toxicity of bottom water was determined by Daphnia magna. Results showed very high mercury content $(2-338 \mathrm{mg} / \mathrm{kg}$ dry weight) in sediment down to $15 \mathrm{~cm}$ depth evenly distributed over the whole lake and low levels for other heavy metals (As, $\mathrm{Cd}, \mathrm{Cu}, \mathrm{Pb}$ and $\mathrm{Zn})$. Water showed low levels of mercury $(0.02 \mu \mathrm{g} / \mathrm{L}$ in bottom and surface water) as for the other heavy metals ( $\mathrm{As}, \mathrm{Cd}, \mathrm{Cu}, \mathrm{Pb}$ and $\mathrm{Zn}$ ). Disturbance of bottom fauna was found for BQI index and O/C index. Disturbance in littoral fauna was seen around the lake (low taxa in six families, ASPT index 5.4. Danish fauna index 4 and acidity index 2). Acute toxicity (Daphnia magna) was high. Levels of mercury in perch were high (muscle $0.6-3.59 \mathrm{mg} / \mathrm{kg}$ and liver $1.05-7.64 \mathrm{mg} / \mathrm{kg}$ ). It was concluded that the underwater detonation of ammunition in Lake Lomtjärn has caused very high levels of mercury in the sediment and a high impact on the ecological chain. In risk assessments aiming to remediation decisions it is recommended early to highlight expected ecological pathways of (mercury) and relevant biomarkers in the ecosystem of concern.

Keywords: ammunition, bottom fauna, dumping, ecological impact, fish, littoral fauna, mercury, mercury fulminate, sediment, underwater destruction.
\end{abstract}

\section{INTRODUCTION}

After Second World War several amounts of ammunition were dumped in about 100 lakes in Sweden [1]. The reason was to make a safe disposal of ageing ammunition which, if left in store, might selfexplode. Dumping of ammunition has also been a legal disposal method until 1970 for the ammunition industry, resulting in additional lakes with large ammunition content. Some of the lakes were also used for underwater destruction of detonators. Possible need for remediation of the Swedish lakes has caused a discussion on safety and costs if collecting the dumped ammunition in opposite to the impact if leaving the ammunition in the lakes. This set focus on the issue of possible long term leaching from dumped ammunition to sediment, water and biota. In this case the mercury impact on lake sediment and biota has been given a special attention.

Metal impact, especially of lead, on lake sediment and biota have been investigated by Förstner et al. [2], Davis et al. [3], Riba et al. [4], Bäckström [5] as well as environmental impact from dumped ammunition by Sjöström et al. [6], Voie [7], U.S. Geological Survey [8] and underwater detonations Liljedahl et al. [9], Karlsson et al. [10] have been discussed in different studies. However, none of these studies could be used to predict the future effects of leaching of mercury from ammunition. 
The literature about mercury in lake sediment, as reviewed by Rasmussen [11] and Richardson [12] indicates that mercury $(\mathrm{Hg})$ can migrate in a variety of inorganic and organic species. In the reducing environment of deep lake sediments, it is feasible that $\mathrm{Hg}$ may be remobilized as organo$\mathrm{Hg}^{2+}$ complexes, $\mathrm{Hg}^{2+}$-organosulphide complexes, and as dissolved or vapour phase. Redox conditions and the stability of organo- $\mathrm{Hg}$ complexes are important influences on the mobility of $\mathrm{Hg}$ that should be considered in the interpretation of surface enrichment. Iron and manganese oxides and hydroxide precipitate are stable in surface sediments due to the higher Eh of surface sediments relative to deep sediments. Enrichment of iron and manganese near the sediment-water interface is likely to be accompanied by a decrease in $\mathrm{Hg}$ mobility, due to the tendency of $\mathrm{Hg}$ and $\mathrm{Hg}$-bound organic complexes to adsorb onto oxide and hydroxide surfaces. Also, the microbiological breakdown of organic material during digenesis appears to be accompanied by a reduction in the integrity of the organo- $\mathrm{Hg}$ association with depth which indicates that $\mathrm{Hg}$ can migrate in a variety of inorganic and organic species.

The toxicity of mercury in aquatic organisms is influenced by the chemical speciation of mercury, the exposure related properties and the sensitivity or tolerance of the organism [13-15]. Inorganic mercury is less acute toxic to aquatic organisms than methyl mercury, but the range in sensitivity between species for either compound is large. These studies show that the toxicity is greater at elevated temperatures, lower oxygen content, reduced salinities in marine environments and in the presence of metals such as zinc and lead.

In general, toxic effects occur because mercury binds to sulfhydryl groups in proteins, alters protein function, reduces protein synthesis, producing non-specific cell injury and in severe cases cell death. Toxicological effects include reproductive impairment, growth inhibition, developmental abnormalities and altered behavioural responses. Reproductive endpoints are generally more sensitive than growth or survival, with embryos and the early developmental stages the most sensitive. Exposure of animals to low concentrations of mercury may not result in mortality directly, but may retard growth thereby increasing the risk of predation [16, 17].

A negative impact of a contaminant in sediment or water can only occur if the contaminant exceeds a certain concentration, if there is an object at risk, and if there is an exposure pathway between the contaminant and the object. In other words, the mere occurrence of a contaminant does not automatically imply a risk for impact. This general principle for mercury is illustrated in Figure 1.

In order to increase the knowledge regarding possible future ecological impact from destruction of ammunition, it has been of interest to find a lake with well-defined natural boundaries, where the sediments are polluted from mercury, and where no other source of pollution can be expected. A study of such a well-defined lake might contribute with information on its present ecological status as well as with information on possible expected long term ecological effects from underwater destruction.

Aim the objective of the study was to evaluate the environmental impact from underwater dumping and explosion of ammunition, containing mercury in a natural wetland (mire) lake, with a special focus on geochemical conditions and ecological effects. It was expected that the ammunition contained mercury fulminate in the detonators.

\section{EXPERIMENTAL, MATERIAL AND METHODS}

\subsection{Limitations}

Limitation in sampling occasions in the Lake Lomtjärn study has been inevitable due to safety restrictions and ongoing activities at the shooting field. 


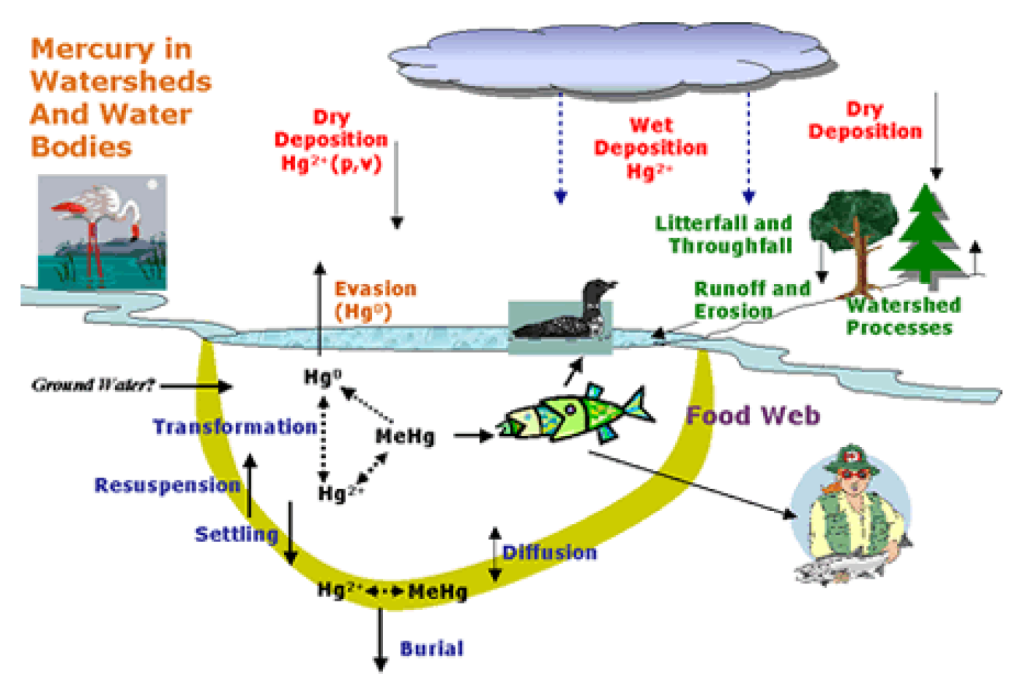

Figure 1: Illustration of the environmental and health risks from mercury in lake sediments. Figure adapted from reports from Minister of Health, Canada [18].

\subsection{Lake Lomtjärn characterization}

Lake Lomtjärn is a small, natural wetland lake (mire) located at a shooting field in the central part of Sweden. The shooting field is located on a water dividing zone ( $200 \mathrm{~m}$ above sea level) with discharge in three directions. The lake area is about $0.005 \mathrm{~km}^{2}$, average depth is $4-5 \mathrm{~m}$ and the catchment area is approx. $0.3 \mathrm{~km}^{2}$. The water retention time of the lake is estimated to be five months. Oxygen level decreases from $6 \mathrm{ppm}$ in surface water to $2 \mathrm{ppm}$ in the bottom water. The $\mathrm{pH}$ is close to $6(6.1$ in surface water and 5.9 close to the bottom), and the concentration of sulphate ranges from $5.5 \mathrm{ppm}$ (surface) to $4.2 \mathrm{ppm}$ (bottom). Alkalinity in the lake ranges from $0.6 \mathrm{meq} / \mathrm{L}$ (surface) to $0.3 \mathrm{meq} / \mathrm{L}$ (bottom) and total organic carbon (TOC) from $7 \mathrm{ppm}$ (surface) to $11 \mathrm{ppm}$ (bottom). Upper sediment $(0-5 \mathrm{~cm})$ has an organic content of $48 \%$ (dry weight of $70 \%)$. Underlying sediment $(20-25 \mathrm{~cm})$ has an organic content of $43 \%$ (dry weight $58 \%$ ) [19].

The lake has neither well-defined outlet nor inlet. Water arrives and leaves the lake diffusely from surrounding wetland. No nearby located lake could be chosen as Reference Lake in order to compare the geochemical and ecological status of natural water, since all water in the area had been more or less affected by varying dumping and/or shooting activities. For this reason, natural background reference levels and conditions have been compared with data from studies of wetland lakes in central, Sweden Swedish Environmental Protection Agency (SEPA) [20]. For specific geochemical background of pollution impact from the day-to-day activities, comparison has been made with nine nearby lakes within the shooting field [19].

\subsubsection{Reference lake}

A reference lake was chosen in the area, Lake Ormtjärn. Both lakes are located within the shooting field and can be expected to have the same background impact from the daily ongoing activities. Lake Ormtjärn is about $0.01 \mathrm{~km}^{2}$, has a depth of $4 \mathrm{~m}$, having no well-defined inlet nor outlet and a retention time of 5 months. The lake is described in more detail in Liljedahl et al. [9]. 


\subsection{Pollution profile}

Regularly dumping of ammunition has occurred in the lake between 1950 and 1980. The ammunition was dumped as pieces or packed in bags that were sunk in the lake. There are no records about the amount of ammunition that has been dumped. A self-induced underwater explosion in the Lake Lomtjärn occurred in the 1980. Ammunition was expected to include old types of detonators containing mercury fulminate. More modern types of detonators, however, contain lead instead of mercury [9]. No other pollution source is known for the lake. A minor background impact might be expected from the day-to-day shooting at the field [21]. The geological geochemistry in the area does not imply naturally increased levels of metals in sediment according to the Swedish Geological Survey [22].

\subsection{Impact scheme, geochemical conditions and ecological effects}

There are several methods for risk assessment within the framework of remediation, where consideration is given to the balance between type of pollutant, the risk of leaching, the sensitivity of surrounding environments and the amount of pollutants, Swedish Environmental Protection Agency [23]. To facilitate the comparison of chemical impact (mercury content) and ecological impact, a simple scheme moderated from different Swedish EPA regulations has been developed within the study.

\subsection{Sampling}

A total of twelve sediment samples were taken during three occasions in May 1999 (S25; 0-5 cm and S26: 20-25 cm) [13] (LOM1-LOM10; 0-5 cm and 10-15 cm respectively) [24] and August 1998 (LOM11; 0-25 cm and 25-50 cm). All of the sediment from the water-sediment interface down to mineralized layers was included. The sediment cores were split into $5 \mathrm{~cm}$ layers onsite, and the samples were stored in plastic boxes at $+4^{\circ} \mathrm{C}$ and kept in dark until analysed.

Water samples were taken at three occasions; March 2000 (W1 at 0.5 m depth) [24], May 2001 (W2 at $4 \mathrm{~m}$ depth) and September 2001 (W3 at $0.5 \mathrm{~m}$ depth). Samples were taken using a Ruthner collector from surface and bottom water. Water samples were stored in $0.5 \mathrm{~L}$ acid rinsed plastic bottles (for metals) and in glass bottles (for completing analysis) respectively, and stored at $+4^{\circ} \mathrm{C}$ and kept in dark until analysed. The $\mathrm{pH}$ was measured on site using a field $\mathrm{pH}$ metre, Check Mate 90 (Metler Toledo).

Bottom fauna were collected at two sites, 10 samples from each, with an Ekman Bottom Grab Sampler. Samples were sieved from coarse material and placed in plastic boxes filled with $98 \%$ ethanol, turned over and stored in dark at $+4^{\circ} \mathrm{C}$ until analysed. Littoral fauna were collected along a spatial 20 m profile by 'long side' and 'short end' of the Lake Lomtjärn using the method M42, Swedish Environmental Protection Agency [20]. Samples were collected $3 \times 5$ times by butterfly net in surface water, air above surface water and at water shore. Samples were collected in plastic boxes filled with $98 \%$ ethanol, turned over and stored in dark at $+4^{\circ} \mathrm{C}$ until analysed.

Fish were sampled by netting. Net meshes were approx. $3 \mathrm{~cm}$. and approximately 70 fish (perch) were caught from different sites of the lake Lomtjärn (Fig.2). Eleven of these were chosen randomly for analysis. Reference netting in one nearby lake resulted in perch from Ormtjärn $(n=4)$. All fish were frozen and transported to laboratory.

\subsection{Analysis}

Sediments were analysed for metals according to EPA methods 200.7 and 200.8 (modified). Metals in water were analysed by a Plasma-mass spectrometre (Sektor) ICP-SFMS. 

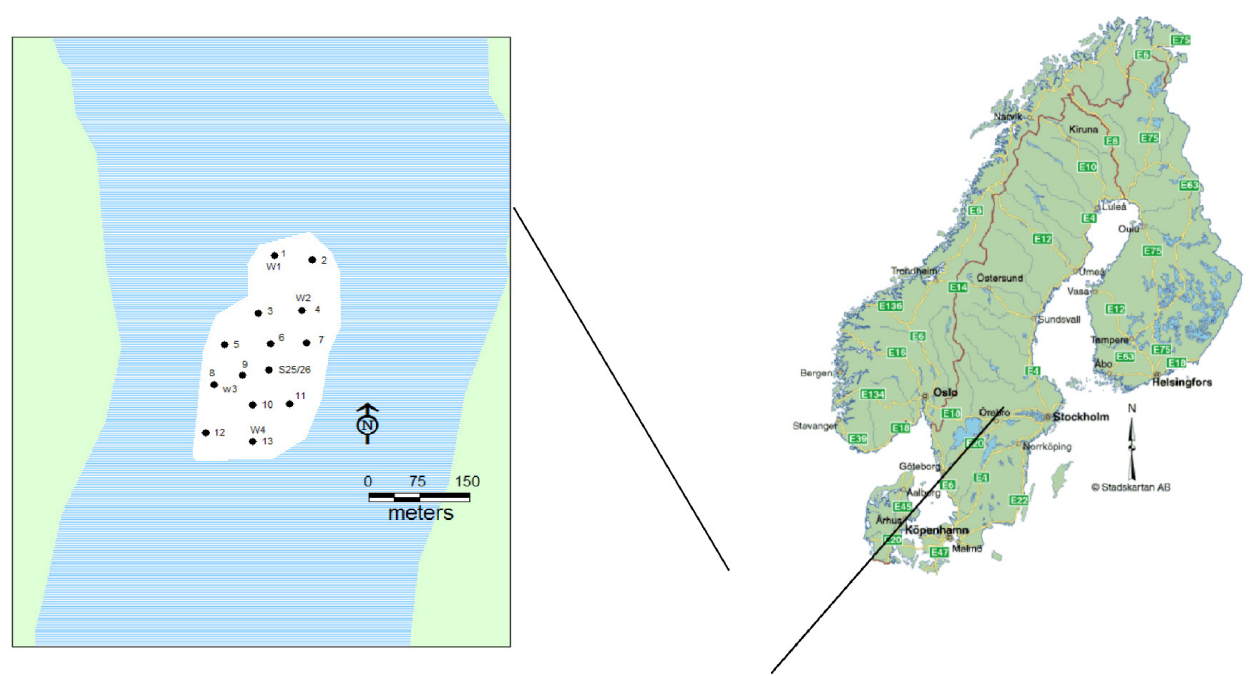

Figure 2: Sampling sites in Lake Lomtjärn.

Table 1: Sampling and analysis. W (water), S (sediment), B (bottom fauna), L (littoral fauna) and F (fish).

\begin{tabular}{|c|c|c|c|c|}
\hline Sample & Date & Level & Total Number & Remarks \\
\hline $\mathrm{W} 1 *$ & $2000-03$ & $0.5 \mathrm{~m}$ & 1 & \\
\hline $\mathrm{W} 2 *$ & $2000-05$ & $4.0 \mathrm{~m}$ & 1 & \\
\hline W3* & $2000-09$ & $0.5 \mathrm{~m}$ & 1 & \\
\hline $\mathrm{W} 4 * *$ & 2000-08 & Surface & 1 & \\
\hline $\mathrm{S} 25 / \mathrm{S} 26 * * *$ & 1999-2003 & $0-5 / 20-25 \mathrm{~cm}$ & $1 \times 2$ & \\
\hline $\mathrm{S} 1-\mathrm{S} 7 * * *$ & $2000-03$ & $0-5 / 10-15 \mathrm{~cm}$ & $1 \times 2$ & \\
\hline S8-S13*** & $2000-05$ & $0-5 \mathrm{~cm}$ & $7 \times 2$ & \\
\hline B1-B2 & $2000-05$ & $0-5 \mathrm{~cm}$ & $2 \times 10 \mathrm{~m}$ & $\begin{array}{l}\text { Abundance, Taxa, BQI } \\
\text { index and } \mathrm{O} / \mathrm{C} \text { index }\end{array}$ \\
\hline L1 & $2000-05$ & & $1 \times 20 \mathrm{~m}$ & $\begin{array}{l}\text { Taxa, ASPT index, } \\
\text { Danish fauna index } \\
\text { and Acidity index }\end{array}$ \\
\hline $\begin{array}{l}\mathrm{F} 1-\mathrm{F} 3 \text { and } \mathrm{F} 6-\mathrm{F} 12 \\
* * * * *\end{array}$ & $2000-09$ & Perch & 3 and 7 & \\
\hline
\end{tabular}

* pH, conductivity, alkalinity. As, $\mathrm{Cd}, \mathrm{Cu}, \mathrm{Hg}, \mathrm{Mn}, \mathrm{Pb}, \mathrm{Zn}$, TNT and its degradation products, RDX, HMX, picric acid. Toxicity Daphnia Magna.

** $\mathrm{NO}_{3} / \mathrm{NO}_{2}$, Ntot, $\mathrm{NH}_{4}, \mathrm{Ptot}, \mathrm{PO}_{4}, \mathrm{pH}$ and conductivity $(\mathrm{mS} / \mathrm{m}), \mathrm{T}^{\circ} \mathrm{C}$, alkalinity, Color.

***As, $\mathrm{Cd}, \mathrm{Cu}, \mathrm{Hg}, \mathrm{Mn}, \mathrm{Pb}$ and $\mathrm{Zn}$, dry weight, organic content. Metyl mercury on 4 samples.

**** Only TNT and its degradation products, RDX, HMX, picric acid. Toxicity Daphnia Magna and Cytotoxicity.

*****Mercury $(\mathrm{Hg})$ in muscle and liver, additional heavy metals in liver (all). 
Explosives in sediment and water were analysed through HPLC and GC/MS according to Sjöström et al. [19].

Bottom fauna was analysed by abundance and taxa. Additional analyses were made for BQI index indicating nutrient and/or organic content in bottom water and for $\mathrm{O} / \mathrm{C}$ index indicating oxygen saturation in the bottom of the lake. Littoral fauna was analysed for Taxa, ASPT index, Danish fauna index and Acidity index, Swedish Environmental Protection Agency [20].

Fish was analysed for age, gender, mercury (liver and muscle) and metal content (muscle) using an ICP-SMS by SGAB Analytica, Luleå, Sweden.

Acute water toxicity was assessed using Daphnia magna. The experiment was performed as a static acute toxicity test, following the procedure described in SS028180 (ISO 6341-1982: Water quality Determination of the inhibition of the mobility of Daphnia magna Straus (Cladocera, Crustacea)). Five animals, neonates $<24 \mathrm{~h}$ old, were added to $30 \mathrm{ml}$ test solution in a $50 \mathrm{ml}$ glass beaker. The exposure time was maximized to $48 \mathrm{~h}$. Water temperature, $\mathrm{pH}$, conductivity and dissolved oxygen were measured at the start and at the end of the test in controls and in the highest and lowest test concentrations. The number of immobilized animals was checked 24 and $48 \mathrm{hrs}$ after test start. The water fleas were considered as immobilized when their appendages or the body failed to move upon prodding. The water fleas were cultured in $500 \mathrm{ml}$ beakers filled with $300 \mathrm{ml}$ reconstituted hard water prepared in untreated tap water according to Klüttgen [25]. The animals were fed daily with algae, Selenastrum capricornutum (approx. $10^{6} \mathrm{cells} / \mathrm{ml}$ ). The water hardness was about $275 \mathrm{mg} \mathrm{CaCO}_{3} / 1$ and the $\mathrm{pH}$ was between 7.9 and 8.2. The temperature was kept at $22 \pm 1{ }^{\circ} \mathrm{C}$ and the photoperiod was $16 \mathrm{~h}$ light and $8 \mathrm{~h}$ dark.

The test solution was prepared by diluting the water sample with the daphnia culture water. The test concentrations were prepared by serial consecutive diluting of the water sample giving a series with a diluting factor of study 1.5. Values for $\mathrm{EC}_{50}$ (probit analysis, SPSS software) were calculated for the 24 and 48 hours of exposure.

A coarse scheme has been developed summarizing the impact from underwater destruction of detonators. The impact level has been moderated from and related to Swedish regulations and recommendations approved by Swedish Environmental Protection Agency (SEPA) for water [20, 26, 27], sediment SEPA [23] bottom fauna and littoral fauna SEPA [28] and fish SEPA [29] and EU [30] including linking to normally occurring follow up activity ('trigger for remediation/ monitoring or other').

For the toxicological analysis, impact levels have been compared according to a procedure presented by Deventer and Zipperle (2004) [31]. The eluate is classified as toxic when it must be diluted 10 to 100 times before no toxic effect is observed in the used test systems. The level of dilution $(<10$, $10-100,>100$ times) is than taken into consideration in the future treatment of the eluate [31].

Based on the recommendations mentioned above, five levels of impact were chosen for summarizing the observed effects:

1. Very low level little or none impact or background level - no action

2. Low level slight impact or near background level - no action

3. Medium level significant impact - normally not causing action

4. High level large impact - action if supported by other risk factors

5. Very high level, very large impact - normally causing action

\section{RESULTS}

\subsection{Sediment and water}

Sediment samples showed a very high content of mercury in all parts of Lake Lomtjärn (Table 2a). Mercury content was highest at level 0-5 cm (338-9 mg/kg dry weight) with a slight decrease at level 
10-15 cm (276-2 mg/kg dry weight). This can be compared with SEPA limit for very high content of mercury in sediment ( $>5 \mathrm{mg} / \mathrm{kg}$ dry weight, Table $2 \mathrm{~b}$ ). The sample below $25 \mathrm{~cm}$ depth had mercury content $(<0.5 \mathrm{mg} / \mathrm{kg}$ dry weight) close to background. The methyl mercury in the samples varied between 0.11 and $1.04 \mathrm{mg} / \mathrm{kg}$ dry weight. All other compounds analysed showed levels below or close to background for the area. No explosives or explosive degradation products were found in the sediments.

Bottom water sample showed a mercury content of $0.02 \mu \mathrm{g} / \mathrm{L}$. Other analysed metals showed low to moderate levels. No explosives or degradation products were detected in the bottom water (Table 2c). Physical and nutrient conditions of the lake showed $\mathrm{pH}$ at 5.1 and conductivity of $0.1-0.2 \mathrm{mS} / \mathrm{m}$. This represents the natural conditions of a typical Swedish forest lake located in a mire area (Table 2d).

Table 2a: Selected geochemistry of the sediment Lake Lomtjärn (metal in mg/kg DS). A complete table of analytical results can be provided by the authors upon request.

\begin{tabular}{lcccccccccccc}
\hline \multicolumn{1}{c}{ Level } & \multicolumn{1}{c}{$\begin{array}{c}\text { Deight } \\
\text { Sample }\end{array}$} & Date & $\begin{array}{c}\text { Organic } \\
(\mathrm{cm})\end{array}$ & $(\%)$ & Content & $\mathrm{As}$ & $\mathrm{Cd}$ & $\mathrm{Cu}$ & $\mathrm{Hg}$ & $\mathrm{Mn}$ & $\mathrm{Pb}$ & $\mathrm{Zn}$ \\
\hline S25 & Sep-1999 & $0-5$ & 88.0 & 82.0 & 10.2 & 1.53 & 116 & 338 & 179 & 94 & 454 \\
S26 & Sep-1999 & $5-10$ & 65.5 & 80.6 & 7.36 & 1.10 & 135 & 276 & 173 & 98.8 & 530 \\
10: $0-5$ & Mar-2000 & $0-5$ & 4.7 & 88.6 & 3.86 & 0.483 & 15.7 & 9.26 & 204 & 23.9 & 107 \\
10: $10-15$ & Mar-2000 & $10-15$ & 4.6 & 90.2 & 1.79 & 0.27 & 11.9 & 2.12 & 219 & 8.07 & 58.7 \\
\hline
\end{tabular}

Table 2b: Guideline values for mercury in sediment.

Data from Swedish EPA [23].

\begin{tabular}{lll}
\hline Class & \multicolumn{1}{c}{ Classification } & $\mathrm{Hg} \mathrm{mg} / \mathrm{kg} \mathrm{DS}$ \\
\hline 1 & Very low content & $\leq 0.15$ \\
2 & Low content & $0.15-0.3$ \\
3 & Moderate content & $0.3-1.0$ \\
4 & High content & $1.0-5$ \\
5 & Very high content & $>5$ \\
\hline
\end{tabular}

Table 2c: Water chemistry of Lake Lomtjärn (bottom water) metals in $\mu \mathrm{g} / \mathrm{L}$.

\begin{tabular}{lcccccccccc}
\hline Sample & $\begin{array}{c}\text { Depth } \\
(\mathrm{m})\end{array}$ & $\mathrm{pH}$ & $\begin{array}{c}\text { Conuctivity } \\
(\mathrm{mS} / \mathrm{m})\end{array}$ & $\mathrm{T}^{\circ} \mathrm{C}$ & $\mathrm{As}$ & $\mathrm{Cd}$ & $\mathrm{Cu}$ & $\mathrm{Hg}$ & $\mathrm{Pb}$ & $\mathrm{Zn}$ \\
\hline $\mathrm{W} 1$ & 4.5 & 5.4 & 2.3 & 13.8 & 0.784 & 0.0304 & 2.56 & 0.0246 & 1.04 & 12.5 \\
$\mathrm{~W} 2$ & 4 & 5.1 & 1.5 & 13.8 & 0.762 & 0.0198 & 1.65 & 0.0189 & 0.88 & 10.8 \\
W3 & 3 & 5.1 & 1.5 & 14.1 & 0.646 & 0.0554 & 1.53 & 0.0166 & 0.793 & 10.8 \\
\hline
\end{tabular}

Table 2d: Physical conditions of Lake Lomtjärn.

\begin{tabular}{cccccccccc}
\hline Sample Date & $\begin{array}{c}\text { Depth } \\
\mathrm{m}\end{array}$ & $\begin{array}{c}\text { Temp } \\
{ }^{\circ} \mathrm{C}\end{array}$ & $\begin{array}{c}\text { pH Conduc- } \\
\text { tivity } \\
\mathrm{mS} / \mathrm{m}\end{array}$ & $\begin{array}{c}\text { Colour } \\
\mathrm{mgPt} / \mathrm{L}\end{array}$ & $\begin{array}{c}\mathrm{N} \text { total } \\
\mathrm{mg} / \mathrm{L}\end{array}$ & $\begin{array}{c}\text { Nitrite } \\
\mathrm{mg} / \mathrm{L}\end{array}$ & $\begin{array}{c}\text { P total } \\
\text { ug/L } / \mathrm{L}\end{array}$ & $\begin{array}{c}\text { Phos- } \\
\text { phate } \mathrm{P} \\
\mathrm{ug} / \mathrm{L}\end{array}$ \\
\hline
\end{tabular}




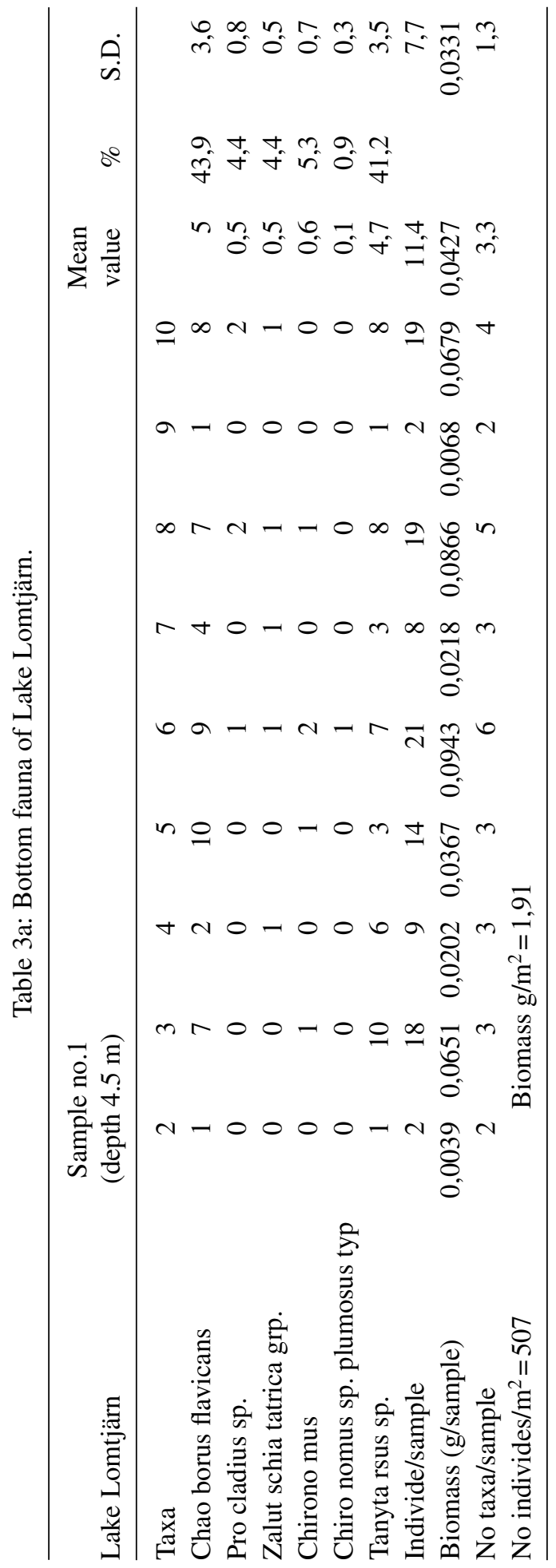




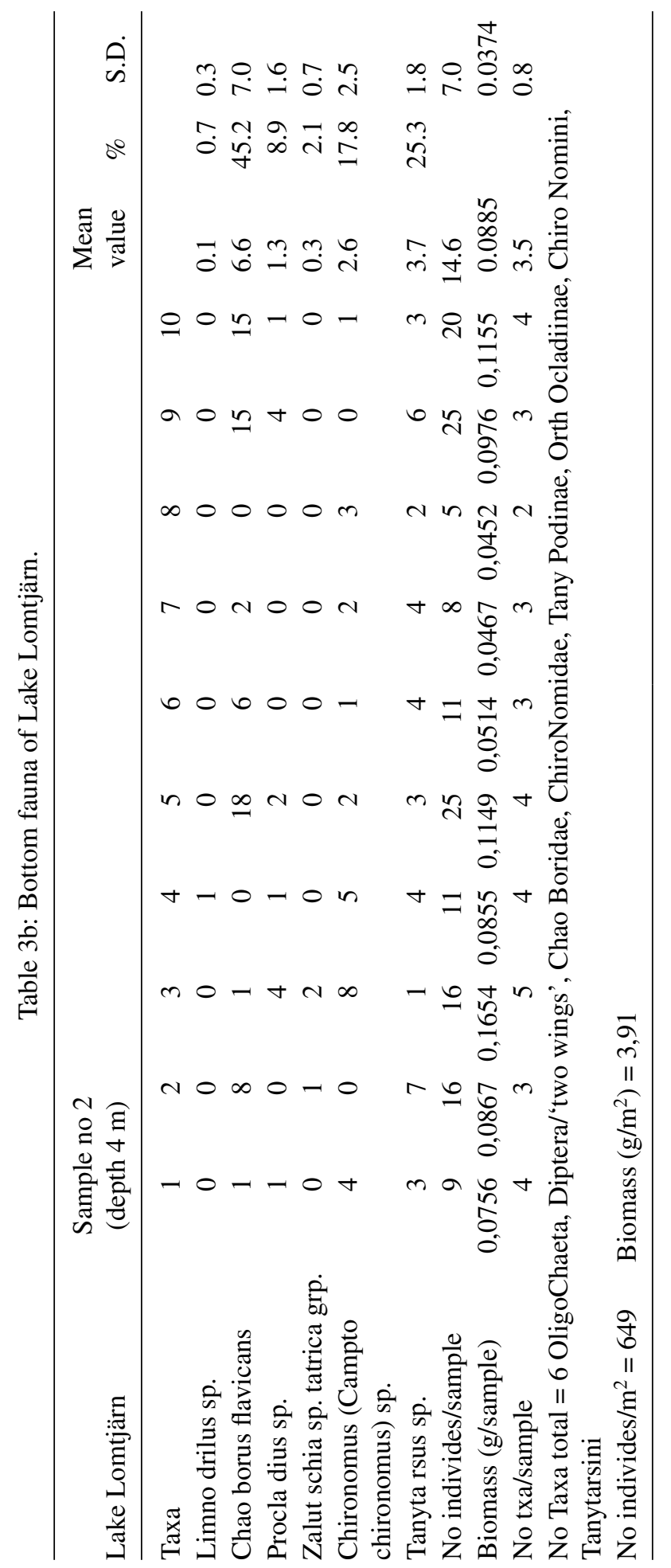




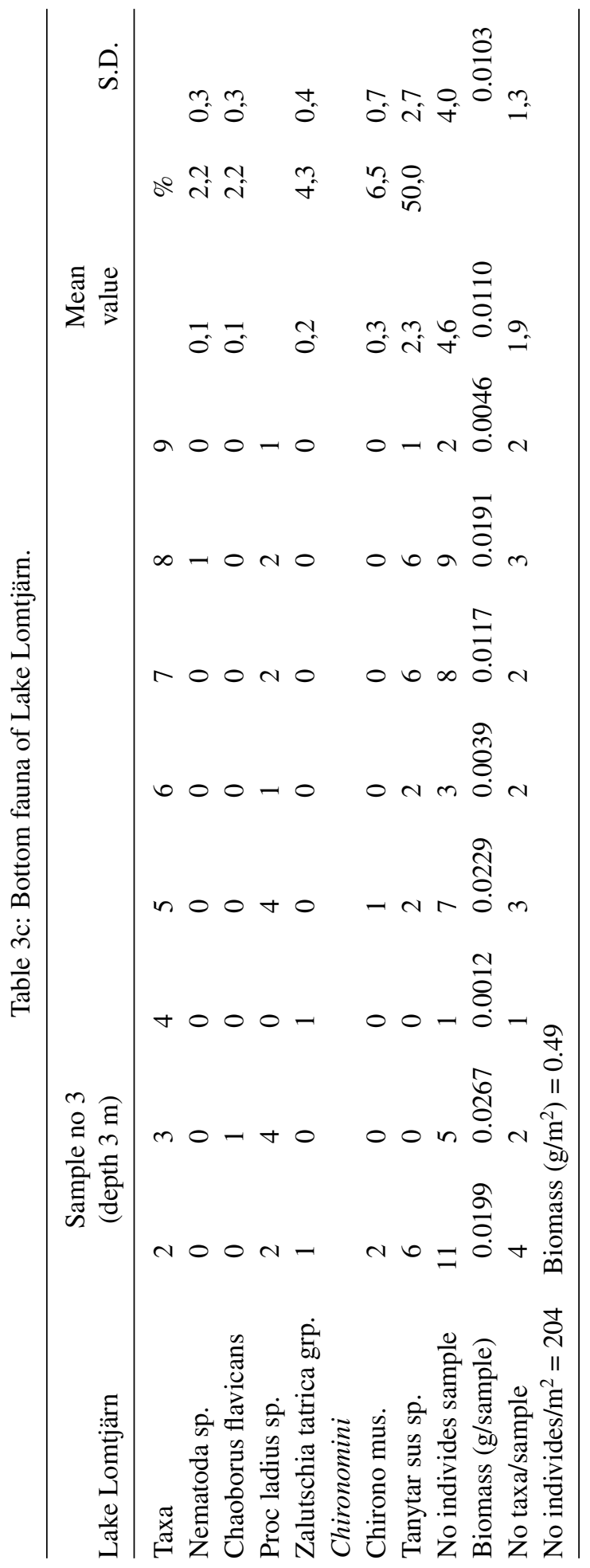


Table 4: Littoral fauna Lake Lomtjärn; taxa, ASPT index, Danish fauna index and acidity index.

\begin{tabular}{ll}
\hline \multicolumn{2}{c}{ Taxa Littoral Fauna in Lake Lomtjärn } \\
\hline Bivalvia & Odonata \\
Sphaeridae & Corduliidae sp. \\
Crustacea & Trichoptera \\
Asellus aquaticus & Cyrnus flavidus \\
Ephemeroptera & Diptera \\
Leptophlebia vespertina & Chironomidae \\
ASPT index 5,4 & \\
Danish fauna index 4 & \\
Acidity index 2 & \\
\hline
\end{tabular}

\subsection{Bottom fauna and littoral fauna}

Bottomfauna samples from Lake Lomtjärn showed six taxa, which are considered relatively low at the depth SEPA [28]. Number of individes was very low with 204 individes $/ \mathrm{m}^{2}$ and as most 694 individes $/ \mathrm{m}^{2}$. The amount of biomass varies between 0.5 and $4 \mathrm{~g} / \mathrm{m}^{2}$.

Littoral fauna showed a total of six taxa in six families (Bivalvia, Crustacea, Ephemeroptera, Odonata, Trichoptera and Diptera). Number of taxa and abundance indicate the disturbed ecological conditions in the lake SEPA [28]. ASPT index was 5.4, Danish fauna index 4 and Acidity index 2 (Table 4).

\subsection{Fish}

The results of the fish analysis from Lake Lomtjärn (Fish 1-Fish11) and the reference lake (Fish 12-Fish 16) can be seen in Table 5. The table also shows the mercury levels from the sediment and bottom water in respective lake.

The levels of mercury in fish from Lake Lomtjärn was in the range of $0.6-3.6 \mathrm{mg} / \mathrm{kg}$ ww in muscle, compared with the levels of mercury in fish in the reference lake, $0.4-0.6 \mathrm{mg} / \mathrm{kg}$ ww in muscle. All samples from fish in Lake Lomtjärn exceeded the Swedish Environmental Protection Agency human-health criterion of $0.5 \mathrm{mg} / \mathrm{kg}$ wet weight of tissue.

\subsection{Toxicity}

The bottom water of Lake Lomtjärn showed toxic effect in juvenile Daphnia magna. The number of immobilized/total animals was 8 of 16 exposed juveniles after 24 hours and 10 of 16 after 48 hours in undiluted sample of bottom water. The mortality in the control was below $10 \%$.

\section{DISCUSSION}

Very high levels of mercury $(2-340 \mathrm{mg} / \mathrm{kg}$ dry weight) were found in the upper $0-15 \mathrm{~cm}$ sediment of Lake Lomtjärn. Besides the mercury fulminate in the dumped ammunition (detonators), no other source for elevated levels of mercury was present, and the underwater detonation of detonators could be established as the direct cause of the high mercury pollution in the lake. 
Table 5: Fish (Perch) analysis from Lake Lomtjärn and from the reference Lake Ormtjärn. (wet weight of tissue: ww).

\begin{tabular}{|c|c|c|c|c|c|c|c|c|}
\hline Samp. & Sex & Age (year) & Weight (g) & $\begin{array}{c}\text { Liver } \\
\text { weight }(\mathrm{g})\end{array}$ & $\begin{array}{l}\text { Muscle Hg } \\
(\mathrm{mg} / \mathrm{kg} \mathrm{ww})\end{array}$ & $\begin{array}{c}\text { Liver Hg } \\
(\mathrm{mg} / \mathrm{kg} \\
\text { ww) }\end{array}$ & $\begin{array}{c}\mathrm{Hg} \text { in } \\
\text { sediment } \\
(\mathrm{mg} / \mathrm{kg} \\
\mathrm{DS})\end{array}$ & $\begin{array}{l}\mathrm{Hg} \text { in } \\
\text { bottom } \\
\text { water } \\
(\mu \mathrm{g} / \mathrm{L})\end{array}$ \\
\hline $\mathrm{F} 1$ & $\mathrm{~F}$ & 11 & 166 & 0.84 & 3.59 & 7.64 & $90-340$ & 0.02 \\
\hline $\mathrm{F} 2$ & $\mathrm{~F}$ & 7 & 124.7 & 0.73 & 1.89 & 2.33 & $90-340$ & 0.02 \\
\hline F3 & $\mathrm{F}$ & 9 & 94.3 & 0.55 & 1.47 & 3.40 & $90-340$ & 0.02 \\
\hline F4 & $\mathrm{F}$ & 6 & 49.6 & 0,45 & 1.38 & 1.73 & $90-340$ & 0.02 \\
\hline F5 & $\mathrm{F}$ & 9 & 102.8 & 1.16 & 1.10 & 1.17 & $90-340$ & 0.02 \\
\hline F6 & $\mathrm{F}$ & 7 & 103.3 & 0.84 & 1.30 & 1.70 & $90-340$ & 0.02 \\
\hline F7 & $\mathrm{F}$ & 10 & 96 & 0.63 & 0.664 & 1.81 & $90-340$ & 0.02 \\
\hline F8 & $\mathrm{F}$ & 4 & 55.1 & 0.52 & 0.620 & 1.30 & $90-340$ & 0.02 \\
\hline F9 & $\mathrm{F}$ & 5 & 66.8 & 0.53 & 1.15 & 1.05 & $90-340$ & 0.02 \\
\hline F10 & $\mathrm{F}$ & 10 & 111.4 & 1.03 & 1.32 & 3.08 & $90-340$ & 0.02 \\
\hline F11 & $\mathrm{F}$ & 9 & 92.3 & 0.51 & 3.05 & 4.68 & $90-340$ & 0.02 \\
\hline *F12-16 & $\mathrm{F} / \mathrm{M}$ & n.d. & n.d. & n.d. & $0.45-0.56$ & n.d. & 3.19 & 0.002 \\
\hline
\end{tabular}

* Reference Lake Ormtjärn, n.d. = Not determined.

The mercury concentration in the muscle tissue from perch in Lake Lomtjärn was 0.62-7.64 mg $\mathrm{kg} / \mathrm{kg}$ ww. According to regulations in the European Community [29], the mercury concentration in fish for consumption shall not exceed $0.5 \mathrm{mg} / \mathrm{kg}$ muscle ww. Swedish EPA has a monitoring program for 26 lakes, analysing mercury content in one-year old perch (muscle). Ten perches were captured from each lake, usually with a weight of 50-100 g [29]. The mercury levels in perch (muscle) in the monitoring program vary between 0.2 and $0.4 \mathrm{mg} / \mathrm{kg}$ ww. A comparison with this data shows that the perch in Lake Lomtjärn all exceed these values. The weight of the perches captured in Lake Lomtjärn (55-166 g) was in the same range of weight as the monitoring perches, but the ages for the perches in Lake Lomtjärn varying between 4 and 11 years. In Sweden it's not unusual that small lakes with limited nutrient conditions result in a large population of small perches with a limited growth rate.

The concentration of mercury in muscle and liver tissue in lake Lomtjärn was in the magnitude of, or higher than, the concentrations found in fish barbel (Barbus graellsii) and bleak (Alburnus alburnus), taken downstream a mercury cell, chlor-alkali factory at the Cinca River in Spain [32]. As comparison, fish taken upstream that factory showed mercury levels around 0.14 and $0.069 \mathrm{mg} / \mathrm{kg}$ ww in muscle and liver respectively, which can be expected in fish taken from unpolluted water. For Swedish conditions, Byrsten and Sandberg [33] showed that mercury concentration in muscle tissue from perch cached in non-polluted water in Sweden was less than $0.0711 \mathrm{mg} / \mathrm{kg}$ ww.

The bioconcentration of a pollutant as mercury in biota is dependent on environmental properties as movement of water, oxygen concentration, $\mathrm{pH}$, etc. In Cinca River below the factory the mercury concentration in the sediment was $0.25-0.400 \mathrm{mg} / \mathrm{kg}$ dry weight, which was 20-200 times lower than the concentrations found in the sediment from Lake Lomtjärn. The body burden of mercury in fish in Lake Lomtjärn was although at the same level as in fish from River Cinca. The bioavailability 
of mercury influences the accumulation of the poison. In Lake Lomtjärn the water is stagnant which facilitates formation of water-insoluble and non-bioavailable complexes and compounds of mercury compared with the situation in River Cinca.

Ten of eleven of the analysed fish were females (Table 5 ). The expected ratio between male and female fish would be 5/6 or vice versa. Since mercury is known to affect sex ratio in other species of vertebrates, [34-37], the hypothesis may be advanced that fish sex ratio may be affected by mercury exposure. Assuming that the proportion between male and female fish is affected by the presence of mercury compounds in the water and prey, the impact on fish is at a high level. A study is planned to be conducted with the aim to verify present observations on mercury exposure and fish sex diversity in Lake Lomtjärn.

The water flea was significantly affected by the undiluted water from the lake. This indicates a very high level of impact on a representative for littoral micro fauna. Undiluted water immobilized $62 \%$ of the animals after 48 hours. The concentration of mercury in the water was $0.012-0.024 \mu \mathrm{g} / \mathrm{L}$. The colour of the water indicates the presence of humus and the $\mathrm{pH}$ was 5.8. Published data on the acute toxicity of inorganic mercury $\left(\mathrm{Hg}^{2+}\right)$ in water fleas are 0.0016 to $0.0052 \mathrm{mg} / \mathrm{L}$ [38]. These values are 100-200 times higher than the mercury concentration found in the lake. Known factors as low $\mathrm{pH}$ and the heavy metals found in the water (Table $2 \mathrm{~b}$ ) may in combination with unknown factors interact and cause the observed $62 \%$ immobilization of the water fleas that were exposed to the water from Lake Lomtjärn.

The bottom and littoral fauna were almost comparable to typical Swedish oligotrophic lakes displaying a few dominating species at high counts, for example Chaoborus, Tanytarsus (Table 3, sample $1,2,3)$. However, the low Acidity index, the tendency of lower than the expected number of taxa and individual counts (Table 3) of certain species, motivates the classification of the littoral fauna as of 'low ecological status'. The ecological impact may be vague, but interestingly species of Chaoborus is known to accumulate mercury from sediment in experimental studies [39]. The hypothesis may be advanced that this possibly constitutes an important path of exposure to fish in the lake Lomtjärn.

The impact from the underwater explosion of ammunition (detonators) in the Swedish natural mire lake is summarized in a coarse impact scheme (Table 6). The scheme may be used to facilitate the discussion of environmental impact from underwater detonated ammunition, remediation needs and prediction of future impacts.

Table 6: Chemical impact of mercury and ecological status - Lake Lomtjärn.

\begin{tabular}{|c|c|c|c|c|c|}
\hline Lake Lomtjärn Level Of Impact & $\begin{array}{c}\text { Very Low } \\
\text { Level }\end{array}$ & $\begin{array}{l}\text { Low } \\
\text { Level }\end{array}$ & $\begin{array}{c}\text { Medium } \\
\text { Level }\end{array}$ & $\begin{array}{l}\text { High } \\
\text { Level }\end{array}$ & $\begin{array}{l}\text { Very High } \\
\text { Level }\end{array}$ \\
\hline \multicolumn{6}{|c|}{ Chemical impact of mercury } \\
\hline Sediment Mercury content $(0-15 \mathrm{~cm})$ & & & & & $\mathrm{X}$ \\
\hline Water Mercury $(\mathrm{Hg})$ content & & $\mathrm{X}$ & & & \\
\hline Biota mercury (Hg) content (Fish liver) & & & & $X$ & \\
\hline Biota Mercury (Hg) content (Fish muscle) & & & & $\mathrm{X}$ & \\
\hline \multicolumn{6}{|c|}{ Ecological status } \\
\hline Water acute toxicity (Daphnia Magna) & & & & $\mathrm{X}$ & \\
\hline Bottom fauna & & & & & \\
\hline Littoral fauna & & & & $\mathrm{X}$ & \\
\hline Biota (Fish condition) & & & & $\mathrm{X}$ & \\
\hline
\end{tabular}




\section{CONCLUSIONS}

No remediation is recommended for Lake Lomtjärn at present. A stop for fish consumption from the lake and the introduction of a monitoring program is proposed. For the long-term assessment of impact in Lake Lomtjärn and from similar typical Swedish forest lake $\mathrm{pH}$, nutrient conditions and oxygen saturation have been identified as possible key 'triggers' in an ecological chain of impact. Considering the high potential of pollution from the sediment and the regional naturally acidic conditions, monitoring of the conditions and $\mathrm{pH}$, will be of key importance for a regularly update regarding any future need for remediation of the lake. Also, if remediation is considered, the hazard of remaining unexploded ordnance and its possible effect on human health and lake ecology must be addressed.

\section{ACKNOWLEDGEMENTS}

The work was financed by Swedish Armed Forces with field assistance from SAAB Bofors Dynamics. A special thanks to Dr. Torbjörn Johnson, PELAGIA.

\section{REFERENCES}

[1] Sjöström, J., Liljedahl, B., Forsman, M., Environmental risk assessment of dumped ammunition in Swedish lakes. Explosives and metals in water and sediments. FOA-R-99-01070-222SE, 2004.

[2] Förstner, U., Kresten, M., Assessment of metal mobility in dredged material and mine waste by pore water chemistry and solid speciation. Chemistry and biology of solid waste. Dredged material and mine tailings, eds Salomon's, W. and Forstner U. Springer Verlag, pp. 214-237, 1988.

[3] Davis, A., Galloway, J.N., Distribution of Pb between sediments and pore water in Woods lake. Adirondack State Park New York, U.S.A. Applied geochemistry, 8, pp. 51-65, 1993. doi: http://dx.doi.org/10.1016/0883-2927(93)90056-M

[4] Riba, I., Garcia-Luque, E., Blasco, J., DelValls, T.A., Bioavailability of heavy metals bound to estuarine sediments as a function of $\mathrm{pH}$ and salinity values. Chemical Speciation and Bioavailability, 15(4), pp. 101-114, 2003. doi: http://dx.doi.org/10.3184/095422903782775163

[5] Bäcktröm, M., Migration and mobility of lead and antimony from heavily polluted lake sediment in On The Chemical State And Mobility Of Lead And Other Trace Elements At The Biosphere Techno Sphere Interface Örebro University, ISBN 91-7668-313-3, 2002.

[6] Sjöström, J., Karlsson, R-M., Qvarfort, U., Environmental risk assessment of dumped ammunition in Natural Waters in Sweden - a Summary. FOI-R-1307-SE, 2004.

[7] Voie, A., Bioavailability of metals from munitions. Norwegian Defence Research Establishment. FFI/Report 2005/00443, 2005.

[8] U.S Geological Survey Survey of Lake Ontario bottom sediment off Rochester, New York, to define the extent of Jettisoned World War II materiel and its potential for sediemt contamination. U.S Geological Survey Open-File report 99-237 and contribution number 1081 of the USGS Great Lake Science Center, 2000.

[9] Liljedahl, B.E., Qvarfort, U., Berglind, R., Sjöström, J., Ecological effects of underwater destruction of detonators in Lake Ormtjärn, Sweden; the impact from lead, Environmental Health and Biomedicine. WIT Transactions on Biomedicine and Health, 15, pp. 291-306, 2011.

[10] Karlsson, R-M., Almström, H., Berglind, R., Environmental effects of underwater blasts - a literature study. FOI-R-1193-SE, 2004.

[11] Rasmussen, P.E., Current methods of estimating mercury fluxes in remote areas: Environmental. Science and Technology, v, 28(13), pp. 2233-2241, 1994.

[12] Richardson, G. Mark. Physical, chemical and geochemical factors influencing mercury accumulation in freshwater fish and humans in Ontario, Canada, 1994. 
[13] Sorvari, J., Sillanpää, M., Influence of metal complex formation on heavy metal and free EDTA and DPTA acute toxicity determined by Daphnia magna. Chemosphere, 33(6), 1119-1127, 1996. doi: http://dx.doi.org/10.1016/0045-6535(96)00251-2

[14] Donkin, S.G., Williams, P.L., Influence of developmental stage, salts and food presence on various end points using Caenorhabtidis elegans fopr aquatic toxicity testing, Environ. Toxicol Chem, 14(12), 2139-2147, 1995.

[15] Dave, G., Xiu, R., Toxicity of mercury, copper, nickel, lead, and cobolt to embryos and larvae of zebrafish, Brachydanio rerio. Arch. Environ, Contam. Toxicol, 21, 126-134, 1991. doi: http://dx.doi.org/10.1007/BF01055567

[16] den Besten, P., de Decker, E., Babut, M., Power, B., DelValls, A., Zago, C., Oen, A., Heise, S., Biological Effect-based sediment Quality in ecological risk assessment for European waters. JSS- J Soils Sediments, 3(3), 144-162, 2003. doi: http://dx.doi.org/10.1065/jss2003.08.084

[17] Szefer, P., Domagala-Wieloszewska, M., Warozocha, J., Garbacik-Wesolowska, Ciesielski, T., Distribution and relationships of mercury, lead, cadmium, copper and zinc in perch (Perca fluviatilis) from the Pomeranian Bay and Szcecin Lagoon, southern Baltic. Food Chemistry, 81, pp. 73-83, 2003. doi: http://dx.doi.org/10.1016/S0308-8146(02)00380-1

[18] Reports from Minister of Health Canada, 2007.

[19] Sjöström, J., Qvarfort, U., Scott, Å., Liljedahl, B., Fällman, Å., Hägglund, L., Berglind, R., Wiklund, A., Environmental risk assessment of areas for combustion, blasting and dumping at the artillery range at Bofors and the industrial area of Björkborn. FOA-R-99-01170-222_ SE, 1999.

[20] Swedish Environmental Protection Agency Environmental Quality Criteria; Lakes and natural waters. Report, 4913, p. 150, ISBN 91-620-4913-S, 1999.

[21] Waleij, A., Karlsson, R-M., Qvarfort, U., Scott Andersson, Å., Lackman, T., Åkerman, J., Wingfors, H., Berglind, R., Sjöström, J., Environmental Impact Assessment of Bofors Shooting field. Swedish report. FOI-R-1118-SE. ISSN 1650-1942, 2003.

[22] Swedish Geological Survey, Geochemical mapping Report, No 68, 1991.

[23] Swedish Environmental Protection Agency: Environmental Quality Criteria; Polluted areas. Swedish report. Report, 4918, p. 112, ISBN 91-620-4918-S, 1999.

[24] Qvarfort, U., Sjöström, J., Bäckström, M., Forsman, M., Extended Environmental Risk Assessment of two lakes within the Bofors Artillery Range area. FOA-R-00-01455-222-SE, 2000

[25] Klüttgen, B., Dülmer, U., Engels, M., Ratte, H.T., ADaM, an artificial freshwater for the culture of zooplankton. Wat. Res., 28, pp. 743-746, 1994.

[26] Swedish Environmental Protection Agency (EPA): Swedish report. Sötvatten Årsskrift från miljövervakningen, ISSN 1652-3962, 2004.

[27] Swedish Environmental Protection Agency: Metaller I kust och havsmiljö, 2004.

[28] Swedish Environmental Protection Agency (SEPA), 2007. Status, potential och kvalitetskrav för sjöar, vattendrag, kustvatten och vatten i övergångszon. En handbok om hur kvalitetskrav i ytvattenförekomster kan bestämmas och följas upp. HANDBOK 2007:4 • UTGÅVA 1 • DECEMBER (In Swedish), 2007.

[29] Swedish Environmental Protection Agency (SEPA), Naturvårdsverkets nationella miljövervakning, programområde Sötvatten (In Swedish), 2011.

[30] The European Community. COMMISSION REGULATION (EC) No 466/2001, of 8 March 2001. 
[31] Deventer, K., Zipperle, J., Ecotoxicological characterization of waste-Method development for determining the ecotoxicological (H14) risk criterion-Landesanstalt fur Umwetschutz Baden-Wurttemberg.LfU, Karlsruhe, 2004 ISSN0949-9477 (Bd. 4, 2004), 2004.

[32] Raldúa, D., Díez, S., Bayona, J.M., Barceló, D., Mercury livels and liver pathology in feral fish living in the vivinity of a mercury cell chlor-alkali factory. Chemosphere, 66, pp. 1217-1225, 2007.

[33] Byrsten, S., Sandberg, A. Metaller och fisk I Persöfjärden/Metals and fish in Persöfjärden. Luleå Technical University, ISSN: 1404-5494, 2005.

[34] Boening, D.W., Ecological effects, transport, and fate of mercury: a general review. Chemisphere, 40, 1335-1351, 2000.

[35] Nordberg, G., Gerhardsson, L., Broberg, K., Mumtaz., Ruiz, P., Fowler, B.A., Interactions in metal toxicology. Handbook on the toxicology of metals, eds G. Norberg, B.A. Fowler, M. Nordberg, \& L.T. Friberg, Elsevier: Amsterdam, pp. 117-145, 2007.

[36] Machenzie, C.A., Lockridge, A., Keith, M., Declining sex ratio in a First Nation Community. Environ. Health Persp, 113(10), pp. 1295-1298, 2005.

[37] Sakamoto, M., Nakano, A., Akagi, H., Declining Minamata male birth associated with increased male fetal death to heavy methylmercury pollution. Environ. Res., 87(2), pp. 92-98, 2001. doi: http://dx.doi.org/10.1006/enrs.2001.4293

[38] Khangarot, B.S., Ray, P.K. Investigation of correlatin between physiological properties of metals and their toxicity to the water flea Daphnia magna Straus. Ecotox. Environ. Safety, 18, pp. 109-120, 1989. doi: http://dx.doi.org/10.1016/0147-6513(89)90071-7

[39] Sjöblom, A., Meili, M., Sundbom, M., The influence of humic substances on the speciation and bioavailability of dissolved mercury and methylmercury, measured as uptake by Chaoborus larvae and loss by volatilization. S Total Env, 261, pp. 115-124, 2000. doi: http://dx.doi. org/10.1016/S0048-9697(00)00630-6 
